\title{
Improving diabetes medication adherence: successful, scalable interventions
}

REVIEW

\author{
This article was published in the following Dove Press journal: \\ Patient Preference and Adherence \\ 23 January 2015 \\ Number of times this article has been viewed
}

\author{
Leah L Zullig ${ }^{1,2}$ \\ Walid F Gellad ${ }^{3,4}$ \\ Jivan Moaddeb 2,5 \\ Matthew J Crowley ${ }^{1,2}$ \\ William Shrank ${ }^{6}$ \\ Bradi B Granger ${ }^{7}$ \\ Christopher B Granger ${ }^{8}$ \\ Troy Trygstad 9 \\ Larry Z Liu ${ }^{10}$ \\ Hayden B Bosworth',2,7,1।
}

'Center for Health Services Research in Primary Care, Durham Veterans Affairs Medical Center, Durham, NC, USA; ${ }^{2}$ Department of Medicine, Duke University, Durham, NC, USA; ${ }^{3}$ Center for Health Equity Research and Promotion, Pittsburgh Veterans Affairs Medical Center, Pittsburgh, PA, USA; ${ }^{4}$ Division of General Internal Medicine, University of Pittsburgh, Pittsburgh, PA, USA; Institute for Genome Sciences and Policy, Duke University, Durham, NC, USA; ${ }^{6}$ CVS Caremark Corporation, ${ }^{7}$ School of Nursing, Duke University, Durham, NC, USA; ${ }^{8}$ Department of Medicine, Division of Cardiology, Duke University School of Medicine, Durham, NC, USA; ${ }^{\circ}$ North Carolina Community Care Networks, Raleigh, NC, USA; ${ }^{10}$ Pfizer, Inc., and Weill Medical College of Cornell University, New York, NY, USA; "Department of Psychiatry and Behavioral Sciences, Duke University School of Medicine, Durham, NC, USA

Correspondence: Hayden B Bosworth Center of Excellence for Health Service Research in Primary Care, Durham Veterans Affairs Medical Center, 4II West Chapel Hill Street, Suite 600,

Durham, NC 2770I, USA

Tel +19192866936

$\mathrm{Fax}+19194165836$

Email hayden.bosworth@duke.edu

\begin{abstract}
Effective medications are a cornerstone of prevention and disease treatment, yet only about half of patients take their medications as prescribed, resulting in a common and costly public health challenge for the US health care system. Since poor medication adherence is a complex problem with many contributing causes, there is no one universal solution. This paper describes interventions that were not only effective in improving medication adherence among patients with diabetes, but were also potentially scalable (ie, easy to implement to a large population). We identify key characteristics that make these interventions effective and scalable. This information is intended to inform health care systems seeking proven, low resource, cost-effective solutions to improve medication adherence.
\end{abstract}

Keywords: medication adherence, diabetes mellitus, chronic disease, dissemination research, implementation research, review

\section{The burden of medication non-adherence}

Medication non-adherence is common and is one of the leading public health challenges facing the US. ${ }^{1}$ It has been estimated that half of chronic disease medications are not taken as prescribed. ${ }^{2-4}$ Even after a prescription has been filled, many patients do not take their medication as prescribed. Within 1 year, over $50 \%$ of patients prematurely discontinue their medications. ${ }^{5,6,7}$ This widespread non-adherence has serious consequences to individual patients and the health care systems that serve them.

Non-adherence has been linked with poorer treatment outcomes ${ }^{8}$ and progression of disease symptoms and complications. ${ }^{9}$ As a result of deteriorating health and adverse events, non-adherence is also associated with increased health services utilization and hospital admission. ${ }^{10-12}$ In addition, the typical non-adherent patient requires three additional medical visits per year, yielding an average increase in treatment costs of $\$ 2,000$ annually. ${ }^{13}$ It has been estimated that medication non-adherence costs US health care systems between $\$ 100-290$ billion annually. ${ }^{14,15}$

The complex medical regimens often required in diabetes make this an ideal condition for examining medication non-adherence. For diabetes specifically, a study conducted among veterans determined that improving adherence could result in annual estimated cost savings ranging from $\$ 661$ million to $\$ 1.16$ billion. ${ }^{16}$ This has repercussions for health care planning and policy design, which may ultimately affect the general population. ${ }^{17}$ We selected diabetes as a model for two reasons. First, diabetes is a complex disease that requires self-management and self-care with focus on medication adherence to achieve good glycemic control. Secondly, examining interventions in one specific disease context (for example, as opposed to looking more broadly at interventions addressing one of many cardiovascular disease risk factors) enabled comparison of unique interventions with a common goal - improving medication adherence among patients with diabetes. 


\section{Interventions to improve medication non-adherence}

While medication non-adherence is a serious and costly challenge, many health service interventions have provided solutions to improve medication adherence in specific contexts and population groups. Because of its frequent reliance on intricate medication therapy, many of these programs have focused on patients with diabetes. However, these proposed solutions often provide inadequate detail to be reproduced, are resource intensive, require substantial policy changes, or are too complex to be scalable (ie, amenable to being "scaled up", that is, taking an intervention that is known to be effective and applying it more broadly in other health care settings and/or with additional patient populations) and cannot be easily adapted for real-world, community settings. ${ }^{3}$ An intervention might have been successful in a controlled, study environment but necessary detail to guide intervention adoption and dissemination is often not reported. Moving forward, researchers, funders, and policy makers must evaluate adherence interventions for their potential for diffusion into practice and return on investment. Rather than "reinventing the wheel", health care institutions or systems can adapt and implement existing proven strategies to promote medication adherence among patients with diabetes.

Prior systematic reviews of medication adherence interventions, ${ }^{3,8}$ while comprehensive, offer little practical advice for clinicians, health care executives, and policymakers in terms of which interventions might be suitable for scale-up and what specific actions they can take to combat non-adherence in their specific settings. Our objective is to provide a general review of diabetes adherence interventions and highlight exemplar research studies that improved medication adherence and patient outcomes using strategies that could be effective if employed in real world health care settings.

\section{Intervention identification}

We reviewed existing literature for successful interventions, that: 1) addressed diabetes medication adherence; and 2) achieved an improvement in medication adherence. Our search was limited to studies indexed in PubMed that were written in English in the previous decade. The specific search strategy used was: "medication adherence"[Mesh] AND "diabetes mellitus"[Mesh] AND "randomized controlled trial"[Publication Type] AND ("2004/01/01"[PDat]: “2014/01/01”[PDat] AND English[lang]).

Using this strategy, we identified 53 potential articles. Articles were subsequently omitted if they met any of the following exclusion criteria: did not address diabetes, did not report results of a randomized trial (eg, protocol only or only information from a baseline assessment), did not significantly improve medication adherence, or medication adherence was not an outcome measure. Scalability was not assessed in this initial screening. After applying exclusion criteria, seven eligible studies remained. ${ }^{18-24}$ Figure 1 describes the article selection process in detail. We describe each intervention's study design, effectiveness, and scalability - or potential for "scaling up" - and broad implementation. Of note, we initially intended that an assessment of cost be an inclusion criterion, but none of the seven identified articles contained a robust cost analysis.

\section{Included interventions}

Of the seven potentially scalable interventions that we identified, four studies involved pharmacy-driven interventions (Table 1) ${ }^{19-22,23}$ Three studies described educational interventions (Table 2). These included two studies that compared educational strategies: teach back versus pictorial images, ${ }^{18}$ and telephone-based versus print. ${ }^{24}$ One study evaluated a face-to-face educational intervention. ${ }^{22}$ These studies were set in both US-based ${ }^{20,21,24}$ and international contexts (Table 3$)^{18,19,22,23}$

\section{Pharmacy-driven interventions}

The pharmacy-driven interventions varied with regard to their setting: retail pharmacies, ${ }^{20,23}$ and public health or health care systems..$^{19,21}$

\section{Retail pharmacies}

Odegard and Christensen conducted a randomized multipharmacy controlled trial to evaluate the impact of a 12-month missed refill follow-up call on adherence. ${ }^{20}$ Eligible patients were taking oral diabetes medication and were 6 days or more late obtaining a prescription refill. After enrollment and randomization, patients who were late for refills in the intervention arm were initially counseled on the importance of adherence, and follow-up calls were conducted between 1 to 4 weeks following the intervention. Participating pharmacists were reimbursed $\$ 10$ per initial and follow-up call or in-store contact with the participant. The intervention successfully improved medication adherence, which was evaluated using pharmacy refill data to calculate a medication possession ratio. For the intervention group, at 6 months medication possession ratio had improved from 0.90 to 0.92 $(P=0.16)$ and at 12 months from 0.85 to $0.90(P<0.01)$. 


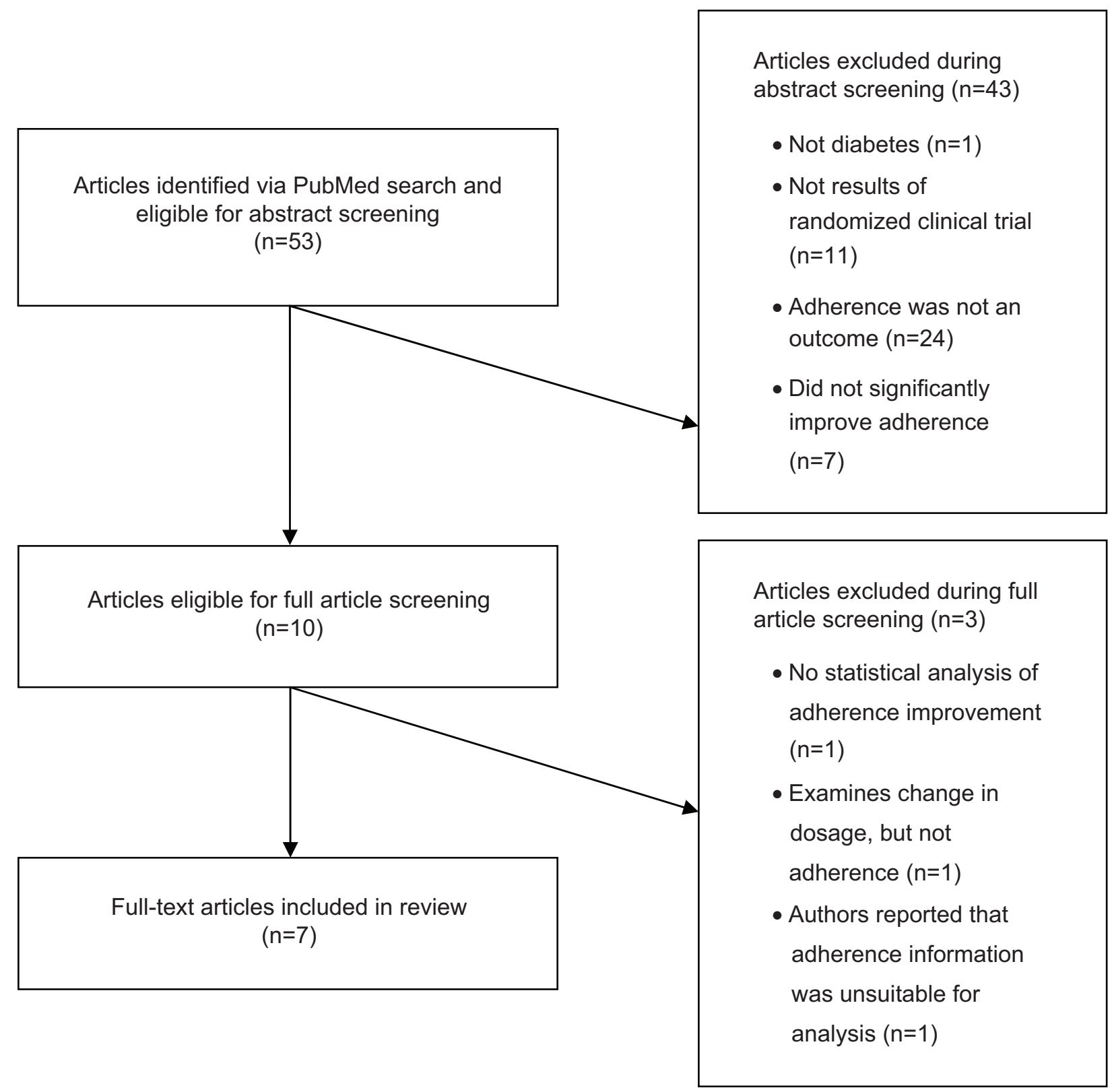

Figure I Article selection process.

Medication possession ratio was nearly unchanged for control participants at 6 months and was slightly worse at 12 months. ${ }^{20}$ Improvements in clinical outcomes were not measured.

Vervloet and colleagues conducted a 6-month, threearm randomized controlled trial. ${ }^{23}$ In the two intervention groups, patients received their oral anti-hyperglycemics in a real time medication monitoring (RTMM) medication dispenser and had their medication use registered in real time. RTMM is similar to the medication event monitoring system and involves an electronic medicine box that registers precisely the date and time when a patient opens it to take their medication (ie, in real time). This real time monitoring provides an advantage over other techniques, such as patients self-report, in that it provides more accurate and prompt information about when a patient takes their medication. Patients in the first group received a short message service (SMS) reminder only if they had not opened their medication dispenser within the agreed time period. In an effort to avoid becoming a nuisance, reminders were sent only once. SMS is a text-messaging component that can be delivered via mobile devices including telephones to exchange short text communications. The combination of these two approaches (RTMM and SMS) enabled 
Table I Description of pharmacy-driven intervention studies

\begin{tabular}{|c|c|c|c|c|}
\hline Authorlyear & Study population & Setting & Design & Interventionist \\
\hline $\begin{array}{l}\text { Obreli-Neto } \\
\text { et al } 20 \mathrm{I}^{19}\end{array}$ & $\begin{array}{l}\text { I94 elderly, diabetic, } \\
\text { and hypertensive patients } \\
\text { completed the study. }\end{array}$ & $\begin{array}{l}\text { Patients were } \\
\text { recruited from } \\
\text { the Public Primary } \\
\text { Health Care Unit } \\
\text { in a municipality } \\
\text { in the Brazilian } \\
\text { State of Sao Paulo, } \\
\text { Brazil. }\end{array}$ & $\begin{array}{l}\text { This was a two-arm randomized, controlled, } \\
\text { prospective clinical trial. The control group } \\
\text { received usual care. The intervention group } \\
\text { received pharmaceutical care intervention } \\
\text { including: assessment of non-adherence; } \\
\text { discussion about the role of medication in health } \\
\text { status; suggestions to physicians concerning } \\
\text { new drug regimens; orientation with respect to } \\
\text { correct drug use and the confection of special } \\
\text { package with a visual reminder that a medication } \\
\text { was taken. All were individualized. }\end{array}$ & $\begin{array}{l}\text { Four pharmacists } \\
\text { conducted the } \\
\text { pharmaceutical care } \\
\text { program once every } \\
6 \text { months. }\end{array}$ \\
\hline $\begin{array}{l}\text { Odegard and } \\
\text { Christensen } \\
2012^{20}\end{array}$ & $\begin{array}{l}265 \text { patients with diabetes, } \\
\text { taking oral diabetes } \\
\text { medications and late for refills } \\
\text { by } \geq 6 \text { days completed the } \\
\text { study. }\end{array}$ & $\begin{array}{l}\text { Patients were } \\
\text { recruited from } \\
\text { four Safeway } \\
\text { pharmacies (a } \\
\text { grocery-based } \\
\text { chain) in the } \\
\text { greater Seattle, } \\
\text { WA, area. }\end{array}$ & $\begin{array}{l}\text { MAP was a randomized, multi-pharmacy, } \\
\text { controlled trial to assess the impact on adherence } \\
\text { of a missed refill follow-up telephone call } \\
\text { intervention. Patients were randomized at the } \\
\text { pharmacy level to usual care or MAP intervention. }\end{array}$ & $\begin{array}{l}\text { Study-trained } \\
\text { pharmacists } \\
\text { delivered the } \\
\text { intervention. Calls } \\
\text { were scheduled } \\
\text { between I week } \\
\text { and I month } \\
\text { following the } \\
\text { intervention. }\end{array}$ \\
\hline
\end{tabular}

$\begin{array}{lll}\text { Shah et al } & \text { I } 27 \text { patients with diabetes } & \text { Patients were } \\ 2013^{21} & \text { and an hemoglobin AIc } \geq 8 \% & \text { recruited from } \\ & \text { who had a provider and } & \text { a county health } \\ & \text { medications filled completed } & \text { system. } \\ & \text { the study. }\end{array}$

Vervloet et al $2012^{23}$

\begin{abstract}
104 type 2 diabetes patients with suboptimal adherence to oral anti-diabetics (pharmacy refill rate of their oral antidiabetic medication of less than $80 \%$ ).
\end{abstract}

\section{Patients were recruited from 40 pharmacies belonging to Mediq, a large Dutch pharmacy chain.}

\begin{abstract}
This was a prospective, randomized, controlled study that compared pharmacist discharge counseling (intervention) with usual patient care (control). Both groups received a 30 -day supply of all discharge medications. Patients in the intervention received I 30-45 minutes counseling

\author{
There was one \\ pharmacist \\ dedicated to \\ discharge counseling \\ all patients in this \\ study.
} session prior to discharge, which emphasized selfcare behaviors.

This was a randomized control trial. Patients were randomized to usual care or one of two intervention groups. In both intervention groups, patients received their oral anti-diabetics in a RTMM medication dispenser and had their medication use registered in real time. Patients in the first group received an SMS reminder if they had not opened their medication dispenser within the agreed time period. Patients in the second group received the RTMM medication dispenser but did not receive SMS reminders.
During the intake in the pharmacy, patients were informed about the study by the pharmacy staff and received the electronic dispenser.

Abbreviations: MAP, medication adherence program; MPR, medication possession ratio; PDC, proportion of days covered; RTMM, real time medication monitoring; SMS, short message service.

researchers to avoid sending reminders to patients who had already taken their medication. Patients in the second group received the RTMM medication dispenser but did not receive SMS reminders. Medication adherence was determined via the RTMM dispensers. Three adherence measures were assessed: days without dosing, missed doses, and doses taken within predefined standardized time windows. Patients receiving SMS reminders took more doses within predefined time windows than patients receiving no reminders: $50 \%$ versus $39 \%$ within a 1 -hour window $(P<0.01)$ up to $81 \%$ versus $70 \%$ within a 4 -hour window $(P<0.01) .{ }^{23}$ In both the SMS and control groups some patients prematurely discontinued the intervention prior to completion of the 6-month study. This occurred for 11 participations (of 56) in the SMS intervention group and 14 (of 48) in the control group. Among those patients that received the SMS messages, the number of reminders received did not differ significantly between patients who reported a positive experience with reminders and those that did not. In both the SMS and control groups some patients 


Outcomes
Outcome measures included
pharmacotherapy adherence (Morisky-
Green) and clinical measurements
(blood pressure, fasting glucose,
hemoglobin Alc, triglycerides, and
total cholesterol).

Outcome measures included changes in medication adherence based on MPR at baseline, 6 , and 12 months.
Outcomes included the overall diabetes medication adherence rate, using the PDC method, and spanning more than 150 days after discharge. Adherence was also assessed at various time points $(30,60,90$, and I 20 days) following completion of the 30-day discharge medications.

The primary outcome measure was adherence to oral anti-diabetics registered with RTMM measured as: I) days without dosing; 2) missed doses; 3) doses taken within predefined standardized time windows.

\begin{tabular}{ll} 
Timeframe & Key features \\
\hline The project lasted & This program \\
36 months, from & was complex and \\
October 2006 to & resource-intensive, \\
October 2009. & $\begin{array}{l}\text { but affected } \\
\text { adherence and } \\
\text { improvement on } \\
\text { several clinical } \\
\text { outcomes. }\end{array}$
\end{tabular}

$\begin{array}{ll}\text { Recruitment } & \text { This program was } \\ \text { occurred from } & \text { implemented in } \\ \text { April 2008 to } & \text { retail pharmacies } \\ \text { October 2009. } & \text { using existing } \\ \text { Participation } & \text { pharmacists who } \\ \text { lasted I2 months. } & \begin{array}{l}\text { were reimbursed } \\ \text { for their effort. }\end{array}\end{array}$

There was

a 3-month

enrollment

period; the study

was conducted in

2010 and 2011 .

The study

occurred over a

6-month period.

\begin{abstract}
This study is unique because it used a one-time inpatient/ transitional education program to improve outpatient medication adherence.
\end{abstract}

RTMM combines electronic monitoring with SMS reminders. RTMM registers data in real time, making it possible to identify a missed dose as it happens.

\begin{tabular}{|c|c|}
\hline$\%$ adherence change & Finding \\
\hline $\begin{array}{l}\text { According to } \\
\text { computerized } \\
\text { dispensed medication } \\
\text { history, } 52.6 \% \text { of } \\
\text { intervention group } \\
\text { patients were adherent } \\
\text { at baseline and } 83.5 \% \\
\text { were adherent after } \\
36 \text { months. No } \\
\text { significant changes were } \\
\text { verified in the control } \\
\text { group. }\end{array}$ & $\begin{array}{l}\text { The intervention group had } \\
\text { significant improvements in } \\
\text { pharmacotherapy adherence, } \\
\text { computerized dispensed } \\
\text { medication history, blood } \\
\text { pressure control, fasting } \\
\text { glucose, hemoglobin Alc, } \\
\text { triglycerides, and total } \\
\text { cholesterol. }\end{array}$ \\
\hline $\begin{array}{l}\text { For the intervention } \\
\text { group, at } 6 \text { months } \\
\text { MPR had improved } \\
\text { from } 0.90 \text { to } 0.92 \\
(P=0.16) \text { and at } \\
12 \text { months from } 0.85 \\
\text { to } 0.90 \text { ( } P<0.01) \text {. MPR } \\
\text { was nearly unchanged } \\
\text { for control participants } \\
\text { at } 6 \text { months and } \\
\text { was slightly worse } \\
\text { at } 12 \text { months. }\end{array}$ & $\begin{array}{l}\text { Baseline adherence was similar } \\
\text { for control and intervention } \\
\text { groups. At I } 2 \text { months, MPR } \\
\text { was significantly improved for } \\
\text { the MAP group compared to } \\
\text { usual care. } \\
\text { The intervention showed } \\
\text { greater effect for patients with } \\
\text { baseline MPR less than } 80 \% \text {. }\end{array}$ \\
\hline $\begin{array}{l}\text { Patients in the } \\
\text { intervention, compared } \\
\text { to controls, had a } \\
\text { greater medication } \\
\text { adherence rate } \\
\text { I } 50 \text { days after discharge } \\
(55.2 \% \text { versus } 34.8 \% \text {; } \\
P=002) \text {. }\end{array}$ & $\begin{array}{l}\text { Patients in the intervention, } \\
\text { compared with the control } \\
\text { group, had greater diabetes } \\
\text { medication adherence rate } \\
\text { I } 50 \text { days after discharge, } \\
\text { rate of follow-up visits and } \\
\text { reduction in hemoglobin Alc. }\end{array}$ \\
\hline $\begin{array}{l}\text { Patients receiving SMS } \\
\text { reminders took more } \\
\text { doses within predefined } \\
\text { time windows than } \\
\text { patients receiving no } \\
\text { reminders: } 50 \% \text { versus } \\
39 \% \text { within a I-hour } \\
\text { window }(P<0.0 \text { I) up } \\
\text { to } 81 \% \text { versus } 70 \% \\
\text { within a } 4 \text {-hour window } \\
(P<0.0 \text { I). }\end{array}$ & $\begin{array}{l}\text { Patients receiving SMS } \\
\text { reminders took significantly } \\
\text { more doses than patients } \\
\text { receiving no reminders. } \\
\text { Reminded patients tended } \\
\text { to miss doses less frequently } \\
\text { than patients not reminded. } \\
\text { Days without dosing were not } \\
\text { significantly different between } \\
\text { the groups. }\end{array}$ \\
\hline
\end{tabular}

prematurely discontinued the intervention prior to completion of the 6-month study. The SMS reminder intervention successfully prompted patients to take significantly more doses than patients not receiving reminders, and reminded patients who tended to miss doses less frequently than those only using the dispenser.

These two pharmacist-driven and pharmacy-based interventions had noteworthy strengths that may increase their potential for scale-up. First, Odegard and Christensen designed an intervention that could be conducted with existing staff resources and requires little additional time (eg, one follow-up phone call by a pharmacist). Secondly, Vervloet et al used a primarily electronic system of monitoring and reminders that was innovative because it required very little human input from an interventionist and targeted patients that need adherence counseling (ie, only patients whose RTMM registered that they had not taken their medicine were sent a reminder). While there is cost to the dispenser system, the automated aspect conserves and prioritizes resource use. 
Table 2 Description of educational intervention studies

\begin{tabular}{|c|c|c|c|c|}
\hline Author/year & Study population & Setting & Design & Interventionist \\
\hline $\begin{array}{l}\text { Negarandeh et al } \\
2013^{18}\end{array}$ & $\begin{array}{l}\text { I } 27 \text { patients with } \\
\text { type } 2 \text { diabetes and } \\
\text { low health literacy } \\
\text { completed the study. }\end{array}$ & $\begin{array}{l}\text { Patients were } \\
\text { recruited from a } \\
\text { secondary care level } \\
\text { diabetes clinic in } \\
\text { Saqqez, } \\
\text { Kurdistan. }\end{array}$ & $\begin{array}{l}\text { This was a three-arm randomized } \\
\text { controlled trial: I) pictorial } \\
\text { image; } 2 \text { ) teach back; and } 3 \text { ) } \\
\text { control group. The intervention } \\
\text { groups received education within } \\
3 \text { weekly } 20 \text { minutes sessions. } \\
\text { Content for the intervention } \\
\text { groups was the same; educational } \\
\text { strategy differed. }\end{array}$ & $\begin{array}{l}\text { A community health } \\
\text { nurse conducted both } \\
\text { intervention groups } \\
\text { and administrated } \\
\text { baseline and follow-up } \\
\text { questionnaires. }\end{array}$ \\
\hline Tan et al $201 \mathrm{I}^{22}$ & $\begin{array}{l}\text { I5I patients with } \\
\text { poorly controlled } \\
\text { diabetes completed } \\
\text { the study. }\end{array}$ & $\begin{array}{l}\text { Patients were } \\
\text { recruited from an } \\
\text { urban government } \\
\text { state hospital and a } \\
\text { rural government } \\
\text { primary care clinic } \\
\text { in Malaysia. }\end{array}$ & $\begin{array}{l}\text { This was a single-blind, } \\
\text { randomized study comparing the } \\
\text { effect of a brief structured face- } \\
\text { to-face education intervention } \\
\text { with usual care. The structured } \\
\text { education program consisted of } \\
3 \text { monthly sessions - two face- } \\
\text { to-face and one via telephone - } \\
\text { addressing self-care practices of } \\
\text { diet, physical activity, medication } \\
\text { adherence, and self-monitoring } \\
\text { of blood glucose. }\end{array}$ & $\begin{array}{l}\text { The study } \\
\text { investigator(s) served } \\
\text { as the interventionist. }\end{array}$ \\
\hline Walker et al 20I I 24 & $\begin{array}{l}526 \text { patients with } \\
\text { elevated hemoglobin } \\
\text { Alc who were } \\
\text { prescribed oral } \\
\text { glucose-lowering } \\
\text { agent(s) were } \\
\text { recruited. }\end{array}$ & $\begin{array}{l}\text { Patients were } \\
\text { members of a health } \\
\text { care worker union } \\
\text { fund based in New } \\
\text { York City. Patients } \\
\text { and/or their spouses } \\
\text { were full-time health } \\
\text { workers. }\end{array}$ & $\begin{array}{l}\text { The I DO study is a randomized } \\
\text { controlled behavioral } \\
\text { intervention comparing the } \\
\text { effectiveness of a telephone } \\
\text { intervention with a print } \\
\text { intervention (active control). }\end{array}$ & $\begin{array}{l}\text { The interventionist } \\
\text { was a health educator }\end{array}$ \\
\hline
\end{tabular}

Abbreviation: $\mathrm{Cl}$, confidence interval.

\section{Public health or health care systems}

In a public health/health system setting, Obreli-Neto et al evaluated the effect of a pharmaceutical care program of medication adherence among elderly diabetic and hypertensive patients. ${ }^{19}$ This study was a randomized, controlled, prospective clinical trial occurring over a 3 -year period. The intervention involved: assessment of non-adherence, discussion about the role of medication in health status, suggestions to physicians concerning new drug regimens, orientation with respect to correct drug use and the confection of a special package with a visual reminder that medication was taken. The intervention was delivered via follow-up attendances and educational group activities. Among the intervention group at 36-months, the study resulted in improvements in self-reported medication adherence (measured using the validated Morisky-Green test translated into Portuguese) $)^{25}$ and computerized dispensed medication history, number of patients reaching adequate values for their blood pressure, and hemoglobin A1c. Specifically, according to computerized dispensed medication history, $52.6 \%$ of intervention group patients were adherent at baseline and $83.5 \%$ were adherent after 36 months. ${ }^{19}$ There were no comparable improvements in the control group.

Shah et al conducted a prospective, randomized, controlled study that compared pharmacist discharge counseling (intervention) with usual patient care (control). ${ }^{21}$ Both groups received a 30-day supply of all discharge medications. Patients in the intervention received one 30-45 minutes 


\begin{tabular}{|c|c|c|c|c|}
\hline Outcomes & Timeframe & Key features & $\%$ adherence change & Finding \\
\hline $\begin{array}{l}\text { Outcome measures } \\
\text { included knowledge, } \\
\text { medication adherence } \\
\text { (measured by 8-item } \\
\text { Morisky Medication } \\
\text { Adherence Scale), } \\
\text { and dietary } \\
\text { adherence. }\end{array}$ & $\begin{array}{l}\text { Patients were } \\
\text { recruited from May } \\
\text { to August } 201 \mathrm{I} \text {. The } \\
\text { intervention was } \\
3 \text { weekly sessions } \\
\text { with outcomes } \\
\text { assessment } 6 \text { weeks } \\
\text { after the intervention. }\end{array}$ & $\begin{array}{l}\text { This study was } \\
\text { successful in a } \\
\text { population with low } \\
\text { literacy and used few } \\
\text { resources. }\end{array}$ & $\begin{array}{l}\text { Medication adherence } \\
\text { reported as percentage } \\
\text { change. }\end{array}$ & $\begin{array}{l}\text { Both teach back and } \\
\text { pictorial image strategies } \\
\text { were beneficial to improve } \\
\text { knowledge about diabetes, } \\
\text { medication, and dietary } \\
\text { adherence among study } \\
\text { participants. }\end{array}$ \\
\hline $\begin{array}{l}\text { Self-care practices } \\
\text { were assessed } \\
\text { using pre- and post } \\
\text { questionnaires. } \\
\mathrm{HbA}_{\mathrm{Ic}} \text { and diabetes } \\
\text { knowledge were also } \\
\text { evaluated. }\end{array}$ & $\begin{array}{l}\text { The intervention } \\
\text { lasted } 3 \text { months and } \\
\text { interventions were } \\
\text { delivered monthly. }\end{array}$ & $\begin{array}{l}\text { This study used a brief } \\
\text { verbal self-efficacy } \\
\text { approach instead of } \\
\text { organized structured, } \\
\text { supervised classes } \\
\text { for multiple behavior } \\
\text { change. It also targeted } \\
\text { a unique study } \\
\text { population - Malaysian } \\
\text { adults with poorly } \\
\text { controlled diabetes. }\end{array}$ & $\begin{array}{l}\text { The difference in } \\
\text { adherence between } \\
\text { the intervention and } \\
\text { usual care groups } \\
\text { was significant } \\
(P<0.01 \text {; } 91.42,95 \% \\
\mathrm{Cl} \text { : } 89.12-93.72 \\
\text { versus } 84.4,95 \% \mathrm{Cl} \text { : } \\
81.76-87.20) \text {. }\end{array}$ & $\begin{array}{l}\text { The intervention group } \\
\text { improved self-monitoring } \\
\text { of blood glucose, physical } \\
\text { activity, hemoglobin Alc, } \\
\text { diabetes knowledge, and } \\
\text { medication adherence. For } \\
\text { within group comparisons, } \\
\text { diabetes knowledge, } \\
\text { hemoglobin Alc level, self- } \\
\text { monitoring of blood glucose, } \\
\text { and medication adherence } \\
\text { improved from baseline in } \\
\text { the intervention group. }\end{array}$ \\
\hline $\begin{array}{l}\text { The primary outcome } \\
\text { was change in } \\
\text { hemoglobin Alc } \\
\text { measured at baseline } \\
\text { and post-intervention } \\
\text { using mail-in kits } \\
\text { with filter paper } \\
\text { methodology. }\end{array}$ & $\begin{array}{l}\text { The study was } \\
\text { I year in duration and } \\
\text { comprised ten calls at } \\
4-6 \text { weeks intervals. }\end{array}$ & $\begin{array}{l}\text { The study was } \\
\text { a comparative } \\
\text { effectiveness study } \\
\text { (telephone versus } \\
\text { print) conducted } \\
\text { in both English and } \\
\text { Spanish among a } \\
\text { lower-income, urban } \\
\text { population. The } \\
\text { majority of participants } \\
\text { were immigrants } \\
\text { working in support of } \\
\text { health care systems. }\end{array}$ & $\begin{array}{l}\text { Medication adherence } \\
\text { reported as percentage } \\
\text { change. }\end{array}$ & $\begin{array}{l}\text { A change in medication } \\
\text { adherence, by claims data } \\
\text { but not by self-reported } \\
\text { measures, was significantly } \\
\text { associated with the } \\
\text { telephonic intervention, but } \\
\text { only among patients not } \\
\text { taking insulin. No diabetes } \\
\text { self-care activities were } \\
\text { significantly corrected with } \\
\text { change in hemoglobin Alc. } \\
\text { Greater intensity of the } \\
\text { intervention ( } \geq 6 \text { calls) was } \\
\text { associated with greater } \\
\text { improvement in Alc. }\end{array}$ \\
\hline
\end{tabular}

counseling session prior to discharge, which emphasized self-care behaviors. Medication adherence was measured using an outpatient pharmacy database and calculated using the validated proportion of days covered method, which reflects the percentage of time that diabetes medications were covered. This study showed both an improvement in medication adherence as well as in clinical outcomes (hemoglobin A1c) and fewer follow-up visits. Patients in the intervention, compared to controls, had a greater medication adherence rate 150 days after discharge ( $55.2 \%$ versus $34.8 \% ; P=002) .{ }^{21}$

These pharmacy-driven public health or health care system interventions have important features. Obreli-Neto et al enrolled a more generalized population; patients were elderly and may have had multiple comorbid conditions. This patient population may make it more relevant to other health care settings and complex patient populations, making it more scalable. Shah et al not only demonstrated an improvement in adherence as measured by outpatient pharmacy records and clinical values, they also showed a potential reduction in health care use (eg, fewer visits), which could be of great advantage to a health care system. ${ }^{21}$

\section{Educational interventions}

Negarandeh and colleagues employed two educational strategies, teach back and pictorial images, to increase knowledge about diabetes and adherence with medication and dietary recommendations among low literacy patients with type 2 diabetes. ${ }^{18}$ The study design was rigorous and involved a 


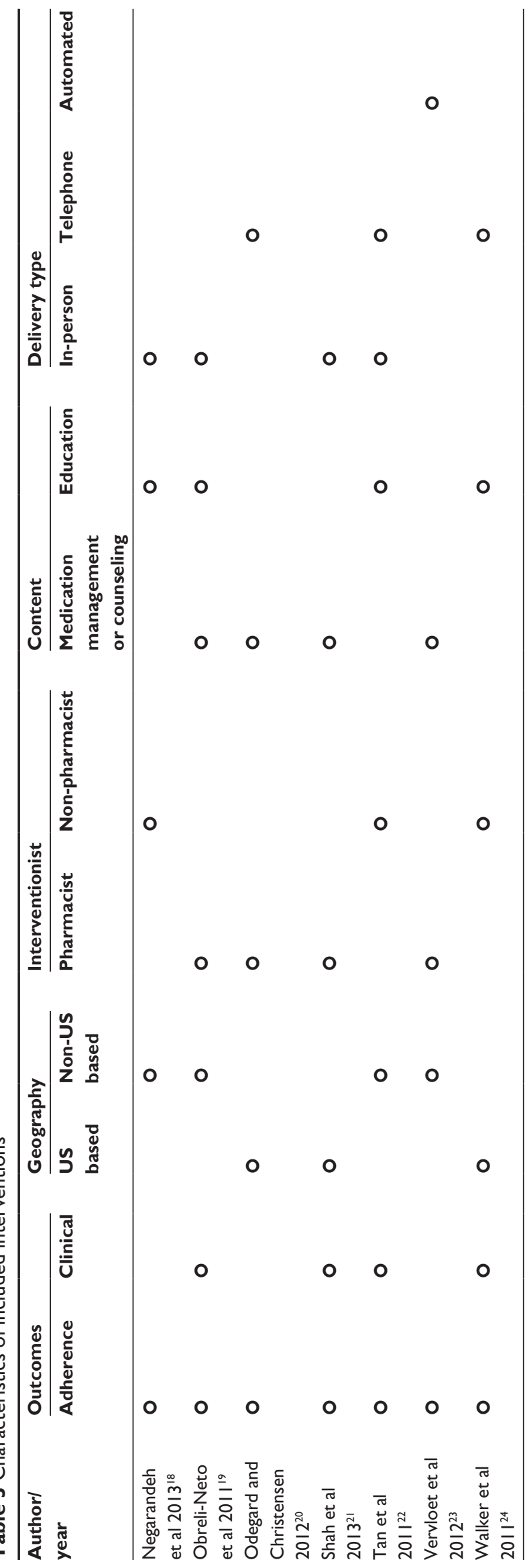

three-arm randomized trial - an arm for each educational strategy, plus a control group. As part of the intervention, a community health nurse conducted three weekly 20 -minute educational sessions. The content of the educational intervention was the same across both intervention arms. The delivery method (ie, teach back or pictorial images) was what was being assessed. "Teach back" essentially involved the interventionist emphasizing a key point throughout the visit and encouraging patients to ask questions. The interventionist then used "teach back" to confirm the patient's understanding. For example, "When you get home and your [partner] asks what the [doctor] said today, what will you tell them?" Patients in the pictorial image group were given the educational content via simple illustrated content. At the conclusion of the 3-week study the mean scores for knowledge, adherence to medication (measured using the 8-item Morisky Medication Adherence Scale), ${ }^{26}$ and diet were significantly improved in the intervention relative to the control groups; these differences persisted 6 weeks after the intervention. Given the relatively short study timeline, clinical outcomes (eg, hemoglobin A1c or blood pressure) were not measured.

Walker and colleagues conducted a one-year randomized controlled trial to evaluate the comparative effectiveness of a behavioral intervention conducted via telephone (intervention) versus print (active control). ${ }^{24}$ Patients in the telephonebased intervention group received approximately ten calls at 4-6 weeks intervals. Medication adherence was measured in two ways. Pharmacy claims data was used to calculate medication possession ratio. Self-reported adherence (ie, the fouritem Morisky Self-Reported Medication Taking Scale) $)^{27}$ was also collected. Using claims data, a change in self-reported medication adherence was significantly associated with the telephonic intervention but only among patients not taking insulin. No diabetes self-care activities were significantly correlated with change in hemoglobin A1c. Greater intensity of the intervention ( $\geq 6$ calls) was associated with greater improvement in hemoglobin A1c.

In Malaysia, Tan and colleagues conducted a 3-month, single-blind, randomized trial to compare the effect of a brief structured education program among patients with poorly controlled diabetes. ${ }^{22}$ There were two monthly face-to-face and one telephone-based interaction in which an interventionist addressed self-care issues including dietary habits, physical activity, medication adherence, and self-monitoring of blood glucose. Self-reported medication adherence was measured using the revised diabetes self-care activities questionnaire, ${ }^{28}$ which has been validated among a Malaysian population. The intervention group improved on each of these self-reported 
self-care behaviors, plus diabetes knowledge and hemoglobin A1c. Within groups, diabetes knowledge, hemoglobin A1c level, blood glucose self-monitoring, and medication adherence improved from baseline to 3-months. The difference in adherence between the intervention and usual care groups was significant $(91.4 \%$ versus $84.4 \%, P<0.01){ }^{22}$

While educational interventions show promise to improve adherence and clinical values, the effort involved in successfully implementing them may be variable making their suitability for scale-up somewhat ambiguous. An advantage of educational interventions is that they can be accomplished by different health professionals such as community health workers, health educators, nurses, and others, which are accessible and affordable in most health care settings. This relatively low resource requirement and ease of use make educational interventions appealing. However, the intensity of intervention required may dampen the utility of these interventions. As Negarandeh et al demonstrated, an additional 20-minute encounter with a community health worker requires relatively little additional burden and could be easily scaled-up for broad use, ${ }^{18}$ however, whether an intervention of this magnitude can improve outcomes is unclear. While more intensive interventions may improve adherence, health care systems may need to consider the resource requirements (eg, Is ten calls reasonable? Is a hybrid of face-to-face and telephone-based interactions feasible?) specific to their needs and resource availability.

\section{Where do we go from here?}

These seven interventions used distinctive approaches and were delivered in unique contexts to improve medication. Integrated systems may have an advantage in the accessibility of ancillary health professionals and medication-related information for implementing these interventions. However, outside of these systems many interventions have been tested without consideration of reach, resources, or cost. ${ }^{29} \mathrm{We}$ assert that we need future research endeavors to be designed mindfully, with specific attention given to applicability, scalability, and sustainability. While we described studies that required resources commonly available in many health care settings, there is a need for additional effective interventions, particularly those that include an assessment of cost. While some of these studies rely on relatively inexpensive and potentially automated technological strategies (eg, text messaging), many also require highly trained personnel (eg, pharmacists) that have the potential to make interventions expensive to implement and scale-up. While these studies could possibly be further disseminated and implemented, it is not always clear that scaling up these interventions would be feasible from a cost-benefit perspective. Despite the importance of cost, relatively few studies provide a robust cost effectiveness analysis. Increased attention to the cost of study implementation, with focus on the linkage with improved patient outcomes, is needed.

Of the seven studies that we featured, interventionists included community health workers, health educators, and pharmacists. Over half of the studies used pharmacists as interventionists. Pharmacists are knowledgeable about pharmacotherapy and may be well trained to provide guidance on adherence. However, they may be an expensive resource. While these studies were effective at improving medication adherence and clinical outcomes, some resource-limited settings might not have additional staff to spare and/or may need to supplement with other skilled laborers such as certified health educators, social workers, licensed nurse practitioners, or other professionals who might be able to provide similar patient services at a reduced cost. Similarly, future innovations might be modified for delivery to groups of patients rather than individuals. In the context of diabetes, group visits have been associated with a greater decreased systolic blood pressure and fewer hospitalizations compared to patients receiving usual care ${ }^{30}$ Providing group visits to facilitate medication adherence might be a scalable and sustainable solution. Another option may be e-learning through innovative applications available through smart-technologies that can be integrated into a patient's day to help increase adherence. This concept is still very novel but with advances in technology and decreasing costs in production this may be an option in the future to help individuals with their health. Group visits can potentially reduce the demand and cost on health care providers and the system. Another way to conserve resources is to match patients with the right level and type of resources. All patients will not need a high intensity pharmacist-driven intervention; a phone call might work just as well for highly motivated patients. Similarly, even among patients that need intense intervention to motivate adherence, they may not require that level of intensity throughout the duration of a program. Several of these interventions relied on technologies, such as "smart" medication dispensers and text messaging. While mobile phone use is ubiquitous among many populations, use of these technologies may not be accessible or appealing to all patients. For example SMS-based reminder systems may work well for some patients, but may not be widely accepted by older patients who may be less familiar with the technology. Matching resources with patient needs is important and may ultimately reduce resource use. 
A key element of scalability and sustainability is resource use and cost or return on investment. During this time of health care reform, providing high quality care, which produces measurable improvements in patients' outcomes at justifiable cost, is paramount. While many studies have shown an improvement in medication adherence, few provide evidence of an improvement in clinical outcome, and fewer still assess the return on investment or thoughtful economic analysis. ${ }^{29}$ In light of the enormous lost opportunity to improve health associated with half of patients not reliably adherent to evidence-based medications, information on the cost-effectiveness of adherence interventions is critical in order to determine which interventions should be translated into clinical practice. We have provided examples of programs that have the potential to be broadly applied to address this critical gap in the delivery of care.

\section{Acknowledgments}

We thank Dale C Slavin, PhD (Safe Use Initiative, Food and Drug Administration) and Kevin A Schulman, MD, MBA (Department of Medicine, Division of General Internal Medicine, Duke University School of Medicine) for insightful comments during manuscript development. Dr Zullig is supported by a Veterans Affairs Health Services Research and Development (HSR\&D) Career Development Award (CDA 13-025).

The views expressed in this article are those of the authors and do not necessarily reflect the position or policy of the Department of Veterans Affairs or the United States government.

\section{Disclosure}

The authors report no conflicts of interest in this work.

\section{References}

1. Osterberg L, Blaschke T. Adherence to medication. NEngl J Med. 2005; 353(5):487-497.

2. Bosworth HB. How can innovative uses of technology be harnessed to improve medication adherence? Expert Rev Pharmacoecon Outcomes Res. 2012;12(2):133-135.

3. Haynes RB, Ackloo E, Sahota N, McDonald HP, Yao X. Interventions for enhancing medication adherence [review]. Cochrane Database Syst Rev. 2008;2:CD000011.

4. Peterson AM, Takiya L, Finley R. Meta-analysis of trials of interventions to improve medication adherence. Am J Health Syst Pharm. 2003;60(7): $657-665$.

5. Granger BB, Bosworth HB. Medication adherence: emerging use of technology. Curr Opin Cardiol. 2011;26(4):279-287.

6. Shah ND, Dunlay SM, Ting HH, et al. Long-term medication adherence after myocardial infarction: experience of a community. Am J Med. 2009; 122(10):961.e7-e13.
7. Vanelli M, Pedan A, Liu N, Hoar J, Messier D, Kiarsis K. The role of patient inexperience in medication discontinuation: a retrospective analysis of medication nonpersistence in seven chronic illnesses. Clin Ther. 2009;31(11):2628-2652.

8. DiMatteo MR, Giordani PJ, Lepper HS, Croghan TW. Patient adherence and medical treatment outcomes: a meta-analysis. Med Care. 2002;40(9):794-811.

9. Schiff GD, Fung S, Speroff T, McNutt RA. Decompensated heart failure: symptoms, patterns of onset, and contributing factors. Am J Med. 2003;114(8):625-630.

10. McDonnell PJ, Jacobs MR. Hospital admissions resulting from preventable adverse drug reactions. Ann Pharmacother. 2002;36(9): 1331-1336.

11. Jha AK, Aubert RE, Yao J, Teagarden JR, Epstein RS. Greater adherence to diabetes drugs is linked to less hospital use and could save nearly $\$ 5$ billion annually. Health Aff (Millwood). 2012;31(8): 1836-1846.

12. Sokol MC, McGuigan KA, Verbrugge RR, Epstein RS. Impact of medication adherence on hospitalization risk and healthcare cost. Med Care. 2005;43(6):521-530.

13. American Pharmacists Association/APhA AP. Medication ComplianceAdherence-Persistence (CAP) Digest. Washington, D.C.: American Pharmacists Association and Pfizer Pharmaceuticals;2003.

14. Lewis A. Non-compliance: a $\$ 100$ billion problem. Remington Rep. 1997;5(4):14-15.

15. Viswanathan $\mathrm{M}$, Golin $\mathrm{CE}$, Jones $\mathrm{CD}$, et al. Interventions to improve adherence to self-administered medications for chronic diseases in the United States: a systematic review. Ann Intern Med. 2012;157(11): 785-795.

16. Egede LE, Gebregziabher M, Dismuke CE, et al. Medication nonadherence in diabetes: longitudinal effects on costs and potential cost savings from improvement. Diabetes Care. 2012;35(12):2533-2539.

17. Touchette DR, Shapiro NL. Medication compliance, adherence, and persistence: current status of behavioral and educational interventions to improve outcomes. J Manag Care Pharm. 2008;14(6):S2-S10.

18. Negarandeh R, Mahmoodi H, Noktehdan H, Heshmat R, Shakibazadeh E. Teach back and pictorial image educational strategies on knowledge about diabetes and medication/dietary adherence among low health literate patients with type 2 diabetes. Prim Care Diabetes. 2013; 7(2):111-118.

19. Obreli-Neto PR, Guidoni CM, de Oliveira Baldoni A, et al. Effect of a 36-month pharmaceutical care program on pharmacotherapy adherence in elderly diabetic and hypertensive patients. Int J Clin Pharm. 2011; 33(4):642-649.

20. Odegard PS, Christensen DB. MAP study: RCT of a medication adherence program for patients with type 2 diabetes. J Am Pharm Assoc (2003). 2012;52(6):753-762.

21. Shah M, Norwood CA, Farias S, Ibrahim S, Chong PH, Fogelfeld L. Diabetes transitional care from inpatient to outpatient setting: pharmacist discharge counseling. J Pharm Pract. 2013;26(2):120-124.

22. Tan MY, Magarey JM, Chee SS, Lee LF, Tan MH. A brief structured education programme enhances self-care practices and improves glycaemic control in Malaysians with poorly controlled diabetes. Health Educ Res. 2011;26(5):896-907.

23. Vervloet M, van Dijk L, Santen-Reestman J, et al. SMS reminders improve adherence to oral medication in type 2 diabetes patients who are real time electronically monitored. Int J Med Inform. 2012;81(9): 594-604.

24. Walker EA, Shmukler C, Ullman R, Blanco E, Scollan-Koliopoulus M, Cohen HW. Results of a successful telephonic intervention to improve diabetes control in urban adults: a randomized trial. Diabetes Care. 2011;34(1):2-7.

25. Bloch KV, Melo AN, Nogueira AR. [Prevalence of anti-hypertensive treatment adherence in patients with resistant hypertension and validation of three indirect methods for assessing treatment adherence]. Cad Saude Publica. 2008;24(12):2979-2984. 
26. Morisky DE, Ang A, Krousel-Wood M, Ward HJ. Predictive validity of a medication adherence measure in an outpatient setting. $J$ Clin Hypertens (Greenwich). 2008;10(5):348-354.

27. Morisky DE, Green LW, Levine DM. Concurrent and predictive validity of a self-reported measure of medication adherence. Med Care. 1986; 24(1):67-74.

28. Naicker AS, Ohnmar H, Choon SK, et al. A study of risk factors associated with diabetic foot, knowledge and practice of foot care among diabetic patients. Int Med J. 2009;16(3):189-193.
29. Milat AJ, King L, Bauman AE, Redman S. The concept of scalability: increasing the scale and potential adoption of health promotion interventions into policy and practice. Health Promot Int. 2013; 28(3):285-298.

30. Jackson GL, Edelman D, Olsen MK, Smith VA, Maciejewski ML. Benefits of participation in diabetes group visits after trial completion. JAMA Intern Med. 2013;173(7):590-592.

\section{Publish your work in this journal}

Patient Preference and Adherence is an international, peer-reviewed, open access journal that focuses on the growing importance of patient preference and adherence throughout the therapeutic continuum. Patient satisfaction, acceptability, quality of life, compliance, persistence and their role in developing new therapeutic modalities and compounds to optimize clinical outcomes for existing disease states are major areas of interest for the journal. This journal has been accepted for indexing on PubMed Central. The manuscript management system is completely online and includes a very quick and fair peer-review system, which is all easy to use. Visit http://www. dovepress.com/testimonials.php to read real quotes from published authors.

\footnotetext{
Submit your manuscript here: http://www.dovepress.com/patient-preference-and-adherence-journal
} 